\title{
New Version of IS-LM: Neoclassical Monetarism
}

\author{
Gürhan Uysal \\ Ondokuz Mayıs University, Samsun, Turkey
}

\begin{abstract}
This study argues three policies for economies. The aim of those policies is to increase total demand by money supply. Global economy currently faces lack of money in markets and recession effect. First, neomerchantalism is to use national currency in bilateral trade. Second, limited money supply is to supply money to sub-regions of economy. Third, neoclassical monetary uses channels in monetary supply. Channels in NCM policy are financial banks and firms. Financial banks and firms distribute money into business markets. Global economies may apply propositions of NCM currently to refresh economies with money.
\end{abstract}

Keywords: neoclassical monetary, central bank, money supply, neomerchantalism

\section{Introduction}

This study discusses neomerchantalism theory, and neoclassical monetarism approach to money supply policy by Central Bank. It proposes that new version of IS-LM may be defined as neoclassical monetarism.

This study suggests three economy policies for economy managements: neomerchantalism, limited money supply policy, and neoclassical monetarism. Neomerchantalim is based on using national currency in international trade. Neoclassical monetarism aims to supply money into markets via firms and financial banks. Goal of both policies is to increase total demand in markets by increasing emission level.

\section{Neomerchantalism: Use of National Currency in International Trade}

Firstly, this study suggests neomerchantalism theory for economies to increase total demand. Neomerchantalism is to use national currency in international trade. It is expected in the era of globalism that it would increase total demand in global economy. Aim of neomerchantalism is to heighten total demand in European economy. Keynes applied IS-LM to increase total demand during 1929 crises. European economy may currently apply neomerchantalism theory.

There are 50 states in European markets. Each has own its currency. Those 50 states may use their national currency in international bilateral trade. Euro will hold its positions as a reserve currency. States will use national currency in trade. For example, Greece will use "drahmi" in bilateral trade with Albania, Romania, Bulgaria, Hungary, others. Further, Bulgaria uses leva for trade. France uses frank for trade with Germany, England, Spain, and Switzerland. Spain uses "peso" in bilateral trade with France. It assumes that neomerchantalisn is more appropriate for trade between neighbour countries.

Gürhan Uysal, PhD/Associate Professor of Management, School of Business, Ondokuz May1s University, Samsun 55139, Turkey.

Correspondence concerning this article should be addressed to Gürhan Uysal, School of Business, Ondokuz Mayis University, Samsun 55139, Turkey.

This paper is presented in the 13th EuroMed Academy of Business Conference, Palermo, Italy. 
In the first step of neomerchantalism, countries use national currency in international bilateral trade. In the second step, there is need of exchange parity because national central banks save other currencies in their portfolios and CBs are needed to exchange these currencies over time. For example, French central bank saves peso, mark, euro, pound, liret, others, and Spain would have frank and others. France and Spain are to exchange those currencies. Bargaining power would establish parity. Suppose it is 1.2, so, France gives 1,000 peso to Spain, and Spanish gives 1,200 frank to France.

In the third step, neomerchantalism theory is more suitable for neighbour countries. For example, France improves trade potential with neighbour countries by using national currency. France uses frank in bilateral trade with Spain, Italy, Slovenia, Switzerland, England, Portugal, others, and neighbours use their currency in trade with France, vice versa. Neomerchantalism theory spreads application worldwide, if European markets adopt it. Therefore, global GDP and sales rise in global economy.

Finally, application of neomerchantalism is based on four steps:

(1) Using national currency in bilateral trade;

(2) Exchange between national central bank;

(3) Coordination of European Central Bank (ECB);

(4) Neomerchantalism is suitable for neighbour countries.

European economy may apply neomerchantalism theory to increase demand. In European market, production PMI data is $46 \%$. In USA it is $49 \%$, in China it is $51 \%$, in Turkey PMI is $49 \%$. For example, German PMI is 0.43 in December, 2019. PMI data is very low in Europe, including Germany. President of ECB, Ms. Lagarde, says that internal demand is decreasing in European economy. Both PMI and internal demand need total demand. Therefore, application of neomerchantalism may increase total demand and PMI in European economy. In addition, it is expected in 2020 that, global economy would experience severe recession due to trade wars.

PMI data shows supply side of business. It is related with production amount and marketing demands. If PMI is low, it means production and demand are low in economic structure. That might be the case for European economy because Europe is behind USA and China in PMI. Neomerchantalism aims to increase internal demand by using national currency in trade (Uysal, 2014). In neomerchantalism, national economies will use their national currency in international trade. Euro currency would hold its positions as international currency. However, England's authorities say that euro does not have economic value for international currency. Therefore, England prefers sterling. In neomerchantalism, European countries, 50 states, will use euro and national currency together in trade within and between.

\section{Gürhan Way of Monetarism}

National economies may currently apply propositions of neoclassical monetarism in global economy under conditions of Covid-19 pandemy.

\section{Limited Money Supply Policy}

Secondly, this study suggests limited money supply policy to supply money into markets. It discusses Gürhan model in monetary. It is based on two factors: limited money supply and economic channels. It is similar to Keynesian approach, because Keynes intervenes economies by IS-LM policy. IS-LM is monetary policy that was used in 1930s. Keynes intervenes economy by IS-LM model. Gürhan Model intervenes economic structure by limited money supply and channel distributions. 
Limited money supply is that central bank does not give money to whole country border. Instead, it gives money into limited region of the country. For example, in Turkey, national central bank gives money into Hakkari region, four-five provinces. If national central bank gives money to all provinces, it means inflation. In Europe, ECB may support Greece or Italy in money instead of supporting 50 states.

Gürhan model is based on Keynesian model in monetary supply. The difference emerges with what Keynes based on IS-LM in monetary supply. Gürhan model is based on limited money supply and neoclassical monetarism. Aim of both is to increase total demand in economy.

Further, Gürhan model is based on using moderators and channels in money in order to increase emission level.

In limited money supply policy, Central Bank distributes money into limited region of country because if CB distributes whole regions in the country, that policy creates inflation. In crises time, for example, in Turkey, Hakkari province demands money from $\mathrm{CB}$ and Turkish Central Bank prints and sends money to Hakkari region. That may be called as limited money supply that doe not create inflation in macro economy. If $\mathrm{CB}$ gives money to whole provinces, that may increase inflation rate. Or in Italy, Italian Central Bank sends liret or euro to southern cities, Bari, that limited money supply does not result in inflation in macro economy. Economies may apply limited money supply policy in crises time, and that policy may increase emission level in economy.

Moreover, European Central Bank (ECB) may supply money to East Europe, to Balkan Countries. ECB prints euro, and it distributes to Balkan Countries. That money may increase total demand and emission level in European economy. This may be an example to limited money supply. Europe is all market structure; however, east Europe is limited region.

Second dimension in Gürhan model is using channels in monetary supply because in direct monetary supply, inflation may appear in economy. For instance, in Turkey, Central Bank uses insurance companies as an economic channel to give money into economy. Insurance companies become economic channels. Turkish CB prints and gives money (lira) to Yapı Kredi Insurance, Ak Sigorta Insurance, Allianz Insurance, others. Those insurance companies become channel to distribute this money into economy. Further, in USA, Non Government Organizations (NGOs) may become economic channels. NGOs recruit 80 million employees in USA, and they are audit and regulation organizations in USA economy. Therefore, they may become channel. So, FED prints money (USD), it gives this money to NGOs; and NGOs distribute this money into whole economy without inflation.

In addition, J. M. Keynes also uses channel in money. Keynesian channel is IS-LM. Keynes uses (I) investments as channel for money. Keynesian model supplies money to markets via public investments (IS) without inflation.

Figures and examples of channel distributions are below:

$$
\text { Central Bank } \longrightarrow \text { Channel } \longrightarrow \text { Economy }
$$

In Turkey, for instance,

Turkish Central Bank $\longrightarrow$ Insurance Companies $\longrightarrow$ Macro Economy

Figure 2. Turkish type of channel money. 
In Turkey in channel model, CB prints money and gives this money to insurance companies in Istanbul; and those insurance companies distribute this money into economy.

In USA, for instance,

FED

$\longrightarrow$ NGOs $\longrightarrow$ Economy

\section{New Version of IS-LM}

Keynes suggested IS-LM policy during 1929 Crises. IS-LM is to inject monetary into economy by fiscal policies. In this model, I is public investments; $\mathrm{S}$ is savings, $\mathrm{L}$ is liquidity, and $\mathrm{M}$ is monetary. Economy management gives liquidity into markets via infrastructure investments. John Hicks figured Keynesian ideas as IS-LM symbol.

This study suggests ISLM-C policy for economies in 2020s. In ISLM-C, C is using economic channels in monetary $(\mathrm{C}=$ Channels $)$. There would not become inflation in economy; if economy management uses economic channels in money supply. This policy (ISLM-C) may be appropriate for England economy. For example, channels are firms and banks in neoclassical monetarism. Global economies are to apply monetary policy in 2020 global recession instead of fiscal policy. Keynes suggested fiscal policy, IS-LM. It was applied in 1930s. However, today economies are to apply monetary policy, which is based on ISLM-C, i.e., economies are to apply money supply policy by using economic channels, which is ISLM-C.

Today there is lack of demand in markets due to withdrawing money that creates global recession. Therefore, national economies are to apply money supply policy to increase demand and emission in markets. This study suggests using channels and ISLM-C policy, similar to Keynes.

ISLM-C is to use channels in money. IS-LM is based on fiscal policy. Infrastructure investments provide liquidity into markets. ISLM-C is based on monetary channels to supply money into markets. For example, Italian Central Bank prints and gives euro to Society General Bank in France, and it gives to Renault Company, and Renault distributes this printed money into French economy. Another example of link is that Polish Central Bank prints euro, gives euro's into Skoda of Czechslovakia, and Skoda Company distributes this printed money into northeastern Europe market. ISLM-C may be applied in other parts of European market, such as Baltic region, Benelux.

Basically, there are two factors in ISLM-C: firm + bank. National Central Bank prints national money, it gives to a financial bank, financial bank gives to a big firm, and firm distributes this printed money into economy and markets.

ISLM-C is based on integrity, integral structure:

ISLM-C: $£$ financial bank + Firm.

In Turkey case, Turkish Central Bank prints 300 billion TLs, for example; CB gives printed money to Ziraat Bank in Turkey, Ziraat Bank gives this money to Koç Holding, and Koç Holding distributes this money into economy because either Ziraat Bank or Koç Holding is variously related with many sectors in economic structure. 300 billion TL at the beginning becomes 1 trillion TL in distribution in this channel.

Further, Italian Central Bank will print and give 1 trillion euro to Society General in France, it will give this money to Renault Company, Renault will distribute 10 trillion euro into markets via multiplier effect. ISLM-C possesses multiplier effects: 1 trillion euro becomes 10 trillion at the end by multiplier effects. There is direct relation in money of ISLM-C in Turkey; however, ISLM-C is applied in Europe via subregions because 
there is European Union relation in European market. It is one market. Subregions may be former Yugoslavia, Baltics, Benelux, Latin parts, others.

So, it means that ISLM-C may be named as Neoclassical Monetarism, which was based on distribution of money via financial bank and big firms.

\section{Neoclassical Monetarism}

Thirdly, this study suggests neoclassical monetarism for economies. Neoclassical Monetarism is based on neoclassic economy theory and monetarist theory. Neoclassical economy explores firms and firm's structure, monetarism is related to money supply. Marshall, Walras, Böhm-Bawerk, Pigou are frontiers of neoclassical economy in 1870s. On the other hand, M. Friedman defended monetarism in 1970s. This study combines theories of neoclassical economy and monetarist school; and it presents neoclassical monetarist theory. For example, P. Samuelson is founder of neoclassical syntez (NCS), which is based on classical economy theory and Keynesian economy. Samuelson tended to apply Keynesian approach in economy management in 1950s. Further, economy discipline is divided into micro and macro level in 1870 s with appearing of neoclassical theory. Neoclassical theory studies micro economy and firm.

Neoclassical Monetarism approach (NCM) is based on financial bank and firm in money. It is using a firm and a bank in money supply into markets. For Turkey case, bank is Ziraat Bank and firm is Koç Holding. Koç Holding distributes money into markets upon Ziraat Bank.

In NCM, firms become channels through which national Central Bank provides liquidity into markets via firm and a financial bank. Keynes provided liquidity into markets via infrastructure investments and fiscal policy, i.e., Keynes (IS-LM) provides liquidity into markets via public investments (fiscal policy). NCM policy provides liquidity into markets via firm and bank. In Turkey case, bank is Ziraat Bank, firm is Koç Holding.

So, NCM's monetary chain is:

Central Bank $\longrightarrow$ Financial $\longrightarrow$ Bank Big $\longrightarrow$ Firm Market

Figure 4. Monetary chain of neoclassical monetarism.

So, NCM may be defined as ISLM-C monetary chain: distributing money into markets via monetary policy, instead of public investments and fiscal policy.

\section{Neomerchantalism, Recession, and Global Economy}

Global economy has recession risk in 2020 due to trade wars. It is expected, it would last longtime. It is assumed, applcation of neomerchantalism, i.e., use of national currency in global trade, decreases risk of recession in global economy, because neomerchantalism would have positive impact on global sales. If neomerchantalism is applied in European economy, it would spread to all global economy.

Global economy had stagflation and inflation during 1970s. President Reagan applied supply side economy to recover from stagflation and inflation. Assumption is that supply side economy increases total production in economy; and it decreases prices level in markets. Prof. Laffer is frontier of supply side economy.

Currently in 2020, global economy and Turkish economy experience higher inflation rates in markets. Economies may apply supply side economy to decrease prices. Global economy is stuck due to trade wars that create stagflation in global economy. Therefore, there are stagflation and inflation in economies in 2020. 
Economies may apply neomerchantalism to get out of stagflation because assumption is that, neomerchantalism has impact on total sales of firms. Secondly, economies may apply neomerchantalism to implement supply side economy. Finally, to get out of stagflation and inflation, economies in global may apply neomerchantalism and supply side economy.

Neomerchantalism is to use national currency in international trade. Aim of neomerchantalism is to increase trade level among economies. Due to trade wars global economy faces stagflation; and use of national currency may stop stagflation.

USA dollar is international currency. Secondly, there are FDI investments in global economy. For example, Some british companies operate in Turkish economy. Many American firms invest in abroad. Thus, dollar and FDIs make neomerchantalism apply in global economy. For example, USA will use dollar in trade with Africa and Europe. In neomerchantalism, European states will use their national currency in trade among them. That policy may increase trade level inside European economy. In Africa, African countries will use their national currencies in trade between them. Thus, use of national currency would increase trade level inside Africa economy. Due to increased trade inside Europe and Africa markets, trade between USA and Africa; and USA and Europe would be heightened. So, global economy would get out of recession and stagflation.

\section{Conclusion}

Those three monetary policies above may be applied by economy managements in different contingencies. Economies including EU may apply propositions of NCM's to save their economies under Covid-19 and global recession effects.

To conclude, global economy applies supply side economy through neomerchantalism to decrease inflation in markets. Many rebellions rebel in Azerbaijan, Lebanon, Chili, others due to higher inflation in economy. In addition, neomerchantalism saves global economy from stagflation due to increased international trade between USA, Africa, and Europe because neomerchantalism (use of national currency) may exist in global economy because there are many FDIs in 21 st century. Economies already invest in each other; and they may use national currency in trade between them.

Application of neomerchantalism theory may increase total demand in global economy (Uysal, 2012), and may stop upcoming global crises.

\section{References}

Skousen, M. (2014). History of economic thought. Ankara: Adres Publishing. Uysal, G. (2012). Neomerchantalism and stagflation: Stopping recession. Ordu SMMMO Bülten Journal, 32, 42-43.

Uysal, G. (2014). Neomerchantalism theory: National currency and IMF. Journal of Business and Economics, 5(12), $249-251$. 